\title{
Bivalve Lembulus bicuspidatus may enhance denitrification in shelf sediment at the Angola-Benguela Frontal Zone.
}

Andreas Neumann ${ }^{\text {a, } 1}$ and Anita Flohr ${ }^{\text {b, } 2}$

${ }^{a}$ University of Hamburg, Institute for Geology, Bundesstraße 55, D-20146 Hamburg, Germany (andreas.neumann@hzg.de)

${ }^{\mathrm{b}}$ Leibniz Center for Tropical Marine Ecology, Fahrenheitstraße 6, D-28359 Bremen, Germany

${ }^{1}$ Helmholtz Zentrum Geesthacht, Institut of Coastal Research, Max-Planck Str. 1, D-21502 Geesthacht, Germany (andreas.neumann@hzg.de)

${ }^{2}$ National Oceanography Centre Southampton, Ocean and Earth Science, University of Southampton, European Way, Southampton, SO14 3ZH, United Kingdom (a.flohr@southampton.ac.uk)

corresponding author: Andreas Neumann, email: andreas.neumann@hzg.de, phone: +494152-87-1880

submission to: African Journal of Marine Science

draft: $2017-12-20$ 


\begin{abstract}
We collected living individuals of the bivalve Lembulus bicuspidatus, which shows an unusual preference for the oxygen-deficient habitat found at the Angola-Benguela Frontal Zone of the southeastern Atlantic. With a series of incubation experiments with $15 \mathrm{~N}$-labelled nitrate as a tracer in combination with membrane-inlet mass spectrometry, we studied the potential contribution of L. bicuspidatus to nitrate reduction in the upper sediment layer. Our preliminary results suggest that L. bicuspidatus enhances nitrate reduction if the oxygen concentration is sufficiently low. The Lembulus-mediated nitrate reduction rate is then similar to the rate of 10 microbial nitrate reduction in the surrounding sediment.
\end{abstract}

\title{
Keywords
}

Benguela Upwelling System, Denitrification, Lembulus bicuspidatus, Oxygen Minimum Zone 


\section{Introduction}

During fieldwork to establish benthic oxygen and nutrient fluxes as part of the GENUS project (Geochemistry and Ecology of the Namibian Upwelling System; reviewed in Emeis et al., in press), an unusually dense population of bivalves in hypoxic bottom water caught our attention off the Kunene River mouth, Namibia, at $17.25^{\circ} \mathrm{S}$. The observation was intriguing because the macrozoobenthos of such habitats is typically dominated by small nematodes and polychaetes (Levin et al. 2003). We identified the dominant bivalve species as Lembulus bicuspidatus (Gould 1845) of family Nuculanidae, which appears to have an unusual, close relationship with the oxygen minimum zone (OMZ) in this region (Zettler et al. 2009). We followed up the assumption of Zettler et al. (2009) that this bivalve species (formerly known as Nuculana bicuspidata) might exploit low-oxygen/ high-nitrate conditions to become the dominant macrozoobenthos species in OMZ areas. Sessile bivalves commonly endure low oxygen episodes by reducing their metabolic rate or by switching to facultative anaerobic metabolism (de Zwaan and Wijsman 1976; Stefano et al. 2015). In contrast, the assumption of Zettler et al. (2009) implies that this bivalve actively exploits the denitrification potential to thrive in oxygen-deficient OMZ waters by utilising nitrate as an electron acceptor. The background to this assumption is that saltwater clams of the family Lucinidae are known to host endosymbiotic bacteria, which enable the lucinids to live, for example, chemolithoautotrophically by sulphide oxidation (Taylor and Glover 2006). Thus, the model for the putative nitrate exploitation by L. bicuspidatus is the lucinid bivalve Lucinoma aequizonata, which hosts nitrate-respiring symbionts to co-respire oxygen and nitrate (Hentschel et al. 1993; Hentschel and Felbeck 1995). We took advantage of the recovered specimens to provide information on the strategy of L. bicuspidatus to adapt to the low-oxygen/high-nitrate conditions at the Angola-Benguela Front (Shannon et al. 1987, von Bodungen et al. 2008) by setting up an improvised experiment. We used nitrate with the stable isotope tracer $15 \mathrm{~N}$ in a series of incubations with different oxygen 
concentrations to test whether L. bicuspidatus contributes to nitrate reduction to N2. Such nitrate reduction in the $\mathrm{OMZ}$ environment is generally attributed to microorganisms (Gallardo et al. 1998; Schulz and Jørgensen 2001; Schulz and Schulz 2005), but a few examples of denitrification in metazoans are also known (Hentschel et al. 1993; Hentschel and Felbeck 1995). The bivalve L. bicuspidatus is found along the tropical and subtropical continental shelf of the eastern Atlantic, including Spain, Western Sahara, Senegal, Angola and Namibia (Gould 1845; Checa 2000; Zettler et al. 2009; Lange et al. 2014), but the highest reported abundance was found in the oxygen-deficient $\mathrm{OMZ}$ at the Angola-Benguela Front (ML Zettler, Leibniz Institute for Baltic Sea Research, Warnemünde, pers. comm.). Coastal upwelling caused by south-easterly trade winds influences the continental shelf at the Angola-Benguela Front. During upwelling, South Atlantic Central Water (SACW) with reduced oxygen concentrations and high nutrient concentrations is pulled onto the Namibian shelf and enables intensive phytoplankton production (Mohrholz et al. 2001, 2008). Subsequent degradation of the plankton masses on the shallow shelf results in the formation of an OMZ. Intensive supply with fresh biomass in combination with high nitrate and low oxygen concentrations in the bottom water creates a setting for substantial elimination of reactive nitrogen to N2 (Kuypers et al. 2005; Nagel et al. 2013; Neumann et al. 2016).

\section{Material \& Methods}

\subsection{Samples}

During cruise MSM 17/3 of the RV Maria S Merian along the Namibian continental margin, in February 2011, water and sediment samples were retrieved from the continental shelf and slope between Lüderitz $\left(26^{\circ} 40^{\prime} \mathrm{S}\right)$ and the Kunene River mouth $\left(17^{\circ} 15^{\prime} \mathrm{S}\right)$ (Figure 1). Undisturbed 
sediment cores were retrieved with a multicorer (Oktopus GmbH, Kiel, Germany) equipped with transparent acrylic (PMMA) tubes (inner diameter $10 \mathrm{~cm}$, length $60 \mathrm{~cm}$ ). Living and empty shells of L. bicuspidatus were recovered by gently sieving the top $5 \mathrm{~cm}$ of the sediment cores in samples of bottom water. After collection, animals and shells were kept dark in bottom-water samples at the in situ temperature $\left(15^{\circ} \mathrm{C}\right)$ in a temperature-controlled laboratory. Water-column samples and sufficient quantities of OMZ-water for incubations were obtained by means of free-flow bottles attached to a multisensor probe CTD.

\subsection{Measurement of dissolved $\mathrm{O}_{2}$ and $\mathrm{N}_{2}$}

Oxygen concentrations were measured with needle-type microoptodes (Presens, Oxy50, 0 $100 \%$ saturation) connected to a Microx TX3 (Presens). The sensor was calibrated with an oxygen-free sodium sulfite solution $\left(0 \% \mathrm{O}_{2}\right.$ saturation) and air-equilibrated water $\left(100 \% \mathrm{O}_{2}\right.$ saturation).

Dissolved $\mathrm{N}_{2}$ in samples from the incubations were measured by membrane-inlet mass spectrometry (MIMS) using a flow-through membrane inlet connected to GAM-200 quadrupole mass spectrometer (InProcess, Bremen). The membrane was a porous hollow fibre with a thin-film coating of silicone, and was mounted coaxially into a stainless steel tee with Swagelok connections. A roughing pump of the mass spectrometer continuously evacuated the inlet. The gaseous permeate of the membrane inlet was dried in an in-line cryo-trap that was cooled with liquid nitrogen. During measurements, the water sample was pumped directly from the incubation vessel through the inlet via gas-tight tubing by means of a peristaltic pump that was mounted downstream of the membrane. The membrane inlet is described in detail in Pohlmann (2010). Mass spectrometer, membrane, and incubations vessels were kept in the 
same temperature- controlled lab, thus samples and membrane had the same temperature. $\mathrm{N}_{2}$ was measured as mass to charge ratios $\mathrm{m} / \mathrm{z} 28$ for ${ }^{28} \mathrm{~N}_{2}, \mathrm{~m} / \mathrm{z} 29$ for ${ }^{29} \mathrm{~N}_{2}$, and 30 for ${ }^{30} \mathrm{~N}_{2}$.

\subsection{Incubations with Lembulus bicuspidatus}

Living animals and empty shells were gently scrubbed with a soft brush to remove sediment residues from the exterior of the shells. Faecal pellets of L. bicuspidatus were carefully collected with a fine Pasteur pipette from the vessel the animals were kept in. For anaerobic treatments, the dissolved oxygen in the sampled OMZ water from station 306 (400 m depth) was removed by purging with pressurised $\mathrm{N} 2$ until the oxygen concentration (see above) was $<1 \mu$ mol $1-1$. For each treatment, either 2 living animals, 2 pairs of empty shells, or 2 faecal pellets of L. bicuspidatus were placed in the oxygen-free $\mathrm{OMZ}$ water supplemented with $15 \mathrm{~N}$-nitrate tracer (98\% purity, $50 \mu \mathrm{mol} 1-1)$ in glass jars with gas-tight butyl rubber seals (Table 1). Due to a limitation of 10 incubation jars per run, we conducted the controls (empty chamber with the tracer, or animals without tracer) in duplicate, and the treatments (animals, shells, or faecal pellets in the presence of the tracer) in triplicate. We ensured that no air bubbles were entrapped during preparation. Controls as well as treatments were incubated for 2 days in darkness at the in situ temperature $\left(15^{\circ} \mathrm{C}\right)$. We conducted three runs in total: 1$)$ with unaltered bottom water from station 305; and, $2+3$ ) with oxygen-free OMZ water from station 306 (Table 1). All animals were used only once for an incubation. All institutional and national guidelines for the care and use of live animals were followed.

The concentrations of dissolved ${ }^{28} \mathrm{~N}_{2},{ }^{29} \mathrm{~N}_{2}$, and ${ }^{30} \mathrm{~N}_{2}$ in the supernatant were then measured immediately with membrane-inlet mass spectrometry (MIMS) without further processing. The $\mathrm{N}_{2} /$ Ar method (Kana et al. 1994) could not be employed here since the bottom water was purged

with $\mathrm{N}_{2}$, which strips not only dissolved oxygen but also argon. Therefore, ${ }^{28} \mathrm{~N}_{2}$ was used 
instead of Ar as the reference to detect variations of ${ }^{29} \mathrm{~N}_{2}$ and ${ }^{30} \mathrm{~N}_{2}$ concentrations (equation 1), while ${ }^{29} \mathrm{~N}_{2}$ and ${ }^{30} \mathrm{~N}_{2}$ were used to detect the tracer turnover against the high background of ambient ${ }^{28} \mathrm{~N}_{2}$. The labelled ${ }^{29} \mathrm{~N}_{2}$ is produced when one ambient ${ }^{14} \mathrm{~N}$ (from e.g. ammonium or nitrate) and one labelled ${ }^{15} \mathrm{~N}$ from the ${ }^{15} \mathrm{NO}_{3}{ }^{-}$combine into one $\mathrm{N}_{2}$ molecule. The combination of two labelled tracer atoms produces ${ }^{30} \mathrm{~N}_{2}$. The saturation concentration of total $\mathrm{N}_{2}$ was taken from published values (Hamme \& Emerson 2004).

$$
\text { Equation 1: } \quad\left[{ }^{30} N_{2}\right]=\frac{m / z 30}{m / z 28}\left[N_{2}\right]
$$

\subsection{Estimation of Lembulus bicuspidatus abundance}

We used the sediment of nine multicores (each with $10 \mathrm{~cm}$ diameter) from two successive multicorer casts, which represents a total area of $0.07 \mathrm{~m}^{2}$. The sediment was sieved through a $500 \mu \mathrm{m}$ sieve and the living L. bicuspidatus individuals in each core were counted. The average abundance per core $\left(78 \mathrm{~cm}^{2}\right.$ area) was then extrapolated to abundance per $\mathrm{m}^{2}$.

\section{Results and Discussion}

\subsection{Habit, habitat, and abundance of Lembulus bicuspidatus}

In February 2011, living specimens of Lembulus bicuspidatus (Figure 2) were found at station MSM17/3-305, at $142 \mathrm{~m}$ water depth (Figure 1). From the coastal station MSM17/3-304, at 35 $\mathrm{m}$ depth, we retrieved only a single, empty Lembulus shell and no living animals. Moreover, this bivalve species was not found at any more-southerly station between the Kunene River 
mouth and Lüderitz, Namibia. At station 305, an average of 4.8 (SD 2.6) living animals were found per sediment core ( $\mathrm{n}=9$ samples), corresponding to an average abundance of 615 (SD 333) individuals per m2. Zettler et al. (2009) found this bivalve in similar habitat and with similar abundance on the Angolan side of the Angola-Benguela Frontal Zone. Multicorer casts are not an ideal choice for macrozoobenthos sampling, but the transparent multicorer tubes enabled us to observe the macrozoobenthos in the sediment with minimal disturbance (Barnett et al. 1984) and at the in situ oxygen level. We measured the oxygen concentration in the supernatant of another core (48 $\mu \mathrm{mol} 1-1)$, which agreed well with in situ measurements from the CTD $(35 \mu \mathrm{mol} 1-1)$. The animals were buried in the uppermost $2 \mathrm{~cm}$ of the muddy sediment, with their siphons protruding approximately $1 \mathrm{~cm}$ into the bottom water. We interpret the protruding siphons as an indicator of ventilation at low oxygen concentration. When outside the sediment, the animals burrowed by means of their flexible, lobe-like foot. During the oxygen-free $(<1 \mu$ mol $1-1)$ incubations, the living animals slightly opened their shells, protruded the siphons into the water, and also produced faecal pellets. We interpret this as an indication of active behaviour in oxygen-free water, which did not cease at the end of the anoxic incubation after 2 days. The bottom water at station 305 was dominated by South Atlantic Central Water (SACW) (cf. Mohrholz et al. 2008), with $48 \mu$ mol oxygen 1-1 and $14 \mu \mathrm{mol}$ nitrate $1-1$. In the $\mathrm{OMZ}$ water that was detected seaward from station 305 , the oxygen concentration was at a minimum in $400 \mathrm{~m}$ water depth, with concentrations as low as $17 \mu \mathrm{mol} 1-1$, whereas the nitrate concentration peaked at $44 \mu \mathrm{mol} 1-1$ (Flohr et al. 2014). These results imply that the centre of the OMZ, with low oxygen and high nitrate water, had sediment contact at $400 \mathrm{~m}$ bottom depth, whereas we found L. bicuspidatus in sediments at $142 \mathrm{~m}$ bottom depth at the time of our survey during the austral summer. However, in austral winter when upwelling is intense enough to pull the oxygen-depleted OMZ water onto the shelf (Mohrholz et al. 2008), L. bicuspidatus might be exposed to the low-oxygen/high-nitrate water of the OMZ. Sediment at station 305 was mud with high porosity and high organic content (Neumann et al. 2016). 
Consistent with Zettler et al. (2009), we found that the bivalve L. bicuspidatus and the gastropod Nassarius vinctus were dominant macrozoobenthos species in the retrieved sediment cores. In a few cores we also found flowery sea pens (Pennatulacea; Vertillidae) and microbial mats on the sediment surface. Additional sediment cores from station 305 were sampled for pore-water concentrations of nitrate, ammonium and N2/Ar, to establish diffusive nitrogen fluxes across the sediment-water interface, for the study by Neumann et al. (2016). In brief, the estimated nitrate uptake by the sediment at station 305 was 0.5 mmol N m-2 d-1, and ammonium was released at a rate of $1.9 \mathrm{mmol} \mathrm{N} \mathrm{m}-2 \mathrm{~d}-1$ from the sediment into the bottom water; the estimated benthic production of $\mathrm{N} 2$ was $0.7 \mathrm{mmol} \mathrm{N} \mathrm{m}-2 \mathrm{~d}-1$. The benthic fluxes are described and discussed in detail in Neumann et al. (2016). Since L. bicuspidatus ventilates and feeds through siphons protruded into the bottom water to bypass the upper sediment layer, we assume that the pore-water concentrations reflect the bivalve's activity only to a small extent, if at all.

\subsection{Bivalve-enhanced denitrification}

Incubation using the in situ oxygen concentration at the sediment surface of station 305 (48 $\mu$ mol 1-1) did not result in any production of $29 \mathrm{~N} 2$ or $30 \mathrm{~N} 2$ (run 1, data not shown), which indicates that no labelled nitrate was reduced to N2. Therefore, we decided to stimulate denitrification by stripping the dissolved oxygen from the incubation water with pressurised N2 gas. The limited number of recovered animals did not permit a proper application of the isotopepairing technique (Risgaard-Petersen et al. 2003) to quantify rates of denitrification and anaerobic ammonium oxidation (anammox), and to identify the pathway of N2 production. Instead, the $15 \mathrm{~N}$-tracer was solely used to observe small quantities of produced, labelled $29 \mathrm{~N} 2$ and 30N2 against the high background concentration of unlabelled, ambient $28 \mathrm{~N} 2$. In the anoxic incubations, no $15 \mathrm{~N}$ from the tracer was recovered as $\mathrm{N} 2$ in treatments with faecal pellets, and 
very low tracer turnover was observed in treatments with empty shells (Figure 3, Table 1). In contrast, significant turnover of $15 \mathrm{~N}$-nitrate to $29 \mathrm{~N} 2$ and $30 \mathrm{~N} 2$ was observed only in treatments with living L. bicuspidatus. For run 2, we estimated average rates of $2.2 \mu \mathrm{mol} \mathrm{d}-1$ (SD 0.2) as 29N2, and $1.4 \mu \mathrm{mol} \mathrm{d}-1$ (SD 0.1) as 30N2 ( $\mathrm{n}=3$ samples). We obtained the same pattern in incubation run 3, but $\mathrm{N} 2$ production was substantially lower in the treatments with L. bicuspidatus, which might indicate a declining metabolic rate of the starving animals (Table 1). Combining our findings, we extrapolated for station 305 that L. bicuspidatus mediated the consumption of ambient nitrate at a rate of $0.3 \mathrm{mmol} \mathrm{N} \mathrm{m-2} \mathrm{d-1} \mathrm{at} \mathrm{an} \mathrm{abundance} \mathrm{of} 615$ animals

$\mathrm{m}-2$. By comparison, the diffusive nitrate flux into the sediment at station 305 was $0.5 \mathrm{mmol}$ N m-2 d-1 (Neumann et al. 2016). Thus, L. bicuspidatus appears as a significant benthic nitrate sink next to the nitrate-reducing microbes in the surrounding sediment. Assuming L. bicuspidatus abundances exceeding $2000 \mathrm{~m}-2$ (Zettler et al. 2009), potential nitrate consumption rates could increase to $0.9 \mathrm{mmol} \mathrm{N} \mathrm{m}-2 \mathrm{~d}-1$ under conditions of nitrate-rich $\mathrm{OMZ}$ water being pulled onto the shelf by upwelling.

\section{Conclusions}

We observed a dense population of the bivalve Lembulus bicuspidatus in oxygen-deficient bottom water at the Angola-Benguela Front. The results of a series of incubations with specimens collected from the sediment, using $15 \mathrm{~N}$-labelled nitrate as a tracer for nitrate reduction to $\mathrm{N} 2$, indicate that the bivalve may substantially enhance the benthic nitrate reduction to N2. We can exclude co-respiration of oxygen and nitrate because no $15 \mathrm{NO} 3-$ tracer was converted to $\mathrm{N} 2$ at an oxygen concentration of $48 \mu \mathrm{mol} 1-1$. However, the actual metabolic path of $\mathrm{N} 2$ production could not be resolved with certainty and the experimental conditions were not ideal, so the findings of this study are to be regarded as preliminary. 
Nevertheless, our study indicates that bivalves thriving in a low-oxygen and high-nitrate environment may play a significant role in benthic nitrogen cycling. This contribution of bivalves might have been overlooked until now because bivalves may be regarded as a source of disturbance in biogeochemical standard methods, such as slurry incubation or isotope-pairing incubation, with small sediment cores from which bivalves are then removed. Hence, we suggest that our preliminary study is repeated with more specimens and a thorough application of isotopepairing incubation to verify that the bivalve L. bicuspidatus indeed enhances the benthic cycling of nitrogen.

\section{Acknowledgements}

We are grateful for the excellent support by crew and officers of the RV Maria S. Merian during the cruise MSM 17/3. We further acknowledge the comments of R. Koppelmann on an earlier draft of this manuscript. This study was financially supported by the German Federal Ministry of Education and Research (BMBF) and contributes to the GENUS project (BMBF 03F0497A). We acknowledge the comments of two anonymous reviewers, which further helped us to improve our manuscript.

\section{Conflicts of interest}

The authors declare that no conflicts of interest exist. 


\section{References:}

Barnett P. R. O., J. Watson, and D. Conelly (1984): A multiple corer for taking virtually undisturbed samples from shelf, bathyal and abyssal sediments. Oceanologica Acta, vol. 7, no. $4,399-408$.

Checa A. G. (2000): Remote biomineralization in divaricate ribs of Strigilla and Selecurtus (Tellinoidea: Bivalvia). J. Moll. Stud. 66, 457-466.

10 de Zwaan A. and T.C.M. Wijsman (1976): Anaerobic metabolism in bivalvia (Mollusca) Characteristics of anaerobic metabolism. Comparative Biochemistry and Physiology Part B: Comparative Biochemistry 54, Issue 3, 313-323.

Flohr, A., van der Plas, A. K., Emeis, K.-C., Mohrholz, V., and Rixen, T. (2014): Spatiotemporal patterns of $\mathrm{C}: \mathrm{N}: \mathrm{P}$ ratios in the northern Benguela upwelling system, Biogeosciences, 11, 885-897, 10.5194/bg-11-885-2014.

Gallardo V.A., Klingelhoeffer E., Arntz W., and Graco M. (1998): First report of the bacterium Thioploca in the Benguela ecosystem off Namibia. J. Mar. Biol. Assoc. UK 78, 1007-1010.

Gould A.A. (1845): Descriptions of shells from the coast of Africa. Boston Journal of Natural History 5: 290-294.

Hamme R. C. and S. R. Emerson (2004): The solubility of neon, nitrogen and argon in distilled water and seawater. Deep-Sea Research, vol. 51, 1517-1528.

Hentschel U., S. C. Cary, and H. Felbeck (1993): Nitrate respiration in chemoautotrophic symbionts of the bivalve Lucinoma aequizonata. Mar. Ecol. Prog. Ser. 94, 35-41.

Hentschel U. and H. Felbeck (1995): Nitrate respiration in chemoautotrophic symbionts of the bivalve Lucinoma aequizonata is not regulated by oxygen. Applied and Environmental Microbiology 61, no. 4, 1630-1633.

Kana T. M., C. Darkangelo, M. D. Hunt, J. B. Oldham, G. E. Bennett, and J. C. Cornwell (1994): Membrane inlet mass spectrometer for rapid high-precision determination of N2, O2, and $\mathrm{Ar}$ in environmental water samples. Analytical Chemistry 66, 4166-4170.

Kuypers, M. M. M., G. Lavik, D. Woebken, M. Schmid, B. M. Fuchs, R. Amann, B. B. Jørgensen, and M. S. M. Jetten (2005): Massive nitrogen loss from the Benguela upwelling system through anaerobic ammonium oxidation. PNAS, vol. 102, no. 18, 64786483.

Lange G., A. Darr, M. L. Zettler (2014): Macrozoobenthos communities in waters off Angola. African Journal of Marine Science 36, 313-321.

Levin, L. A. , Rathburn A. E., Gutiérrez D., Muñoz P, Shankle A. (2003). Bioturbation by symbiont-bearing annelids in near-anoxic sediments: implications for biofacies models and paleo-oxygen assessments. Palaeogeography, Palaeoclimatology, Palaeoecology 199: 129140 . 
Mohrholz, V., Schmidt, M., and Lutjeharms, J. R. E.(2001): The hydrography and dynamics of the Angola-Benguela Frontal Zone and environment in April 1999, South African Journal of Marine Science, 97, 199-208.

Mohrholz, V., Bartholomae, C. H., Plas, A. K. v. d., and Lass, H. U. (2008): The seasonal variability of the northern Benguela undercurrent and its relation to the oxygen budget on the shelf, Continental Shelf Research 28, 424-441.

10 Nagel, B., K.-C. Emeis, A. Flohr, T. Rixen, T. Schlarbaum, V. Mohrholz, and A. van der Plas (2013): N-cycling and balancing of the N-deficit generated in the oxygen minimum zone over the Namibian shelf-An isotope-based approach, J. Geophys. Res. Biogeosci., 118, 361-371, doi:10.1002/jgrg.20040.

Neumann, A., N. Lahajnar, and K.-C. Emeis (2016): Benthic remineralisation rates in shelf and slope sediments of the northern Benguela upwelling margin. Journal of Continental Shelf Research 113, 47-61.

Pohlmann J. (2010): Optimierung eines Membraneinlasses für die Messung am Membran Inlet Massenspektrometer. Diplomarbeit (Master Thesis), Fachbereich Angewandte Naturwissenschaften, Fachhochschule Lübeck.

Risgaard-Petersen N., L. P. Nielsen, S. Rysgaard, T. Dalsgaard, and R. L. Meyer (2003): Application of the isotope pairing technique in sediments where anammox and denitrification coexist. Limnol. Oceanogr.: Methods 1, 63-73.

Schulz, H. N., B. B. Jørgensen (2001): Big Bacteria. Annu.Rev.Microbiol. 55, 105-137.

Schulz, H. N., Schulz, H. D. (2005) Large sulfur bacteria and the formation of phosphorite. Science 307, 416-418.

Stefano G. B., K. J. Mantione, F. M. Casares, R. M. Kream (2015): Anaerobically functioning mitochondria: evolutionary perspective on modulation of energy metabolism in Mytilus edulis. Invertebrate Survival Journal 12, 22-28.

Taylor J. D. and E. A. Glover (2006): Luciniae (Bivalvia)- the most diverse group of chemosymbiotic molluscs. Zoological Journal of the Linnean Society 148, 3, 421-438.

Zettler et al. (2009): Macrozoobenthos diversity in an oxygen minimum zone of northern Namibia. Mar. Biol. 156: 1949-1961. 


\section{Tables}

Table 1: Results of anoxic incubations of $N$. bicuspidata with ${ }^{15} \mathrm{~N}$-labelled nitrate. Production rates of labelled ${ }^{29} \mathrm{~N}_{2} /{ }^{30} \mathrm{~N}_{2}$ are given as average with 1 standard deviation in brackets.

\begin{tabular}{llllll}
\hline run & date & \multicolumn{1}{c}{ treatment } & $\mathrm{N}$ & \multicolumn{2}{c}{ average $\mathrm{N}_{2}$ production (sd) } \\
& & & & ${ }^{29} \mathrm{~N}_{2}$ & ${ }^{30} \mathrm{~N}_{2}$ \\
$\left(\mu \mathrm{mol} \mathrm{d}^{-1}\right)$ & \\
& & & & & \\
\hline & & & 2 & $0.0(0.1)$ & $0.0(0.0)$ \\
2 & $2011 / 02 / 24$ & chamber $+{ }^{15} \mathrm{~N}$-tracer & 2 & $0.0(0.1)$ & $0.0(0.0)$ \\
2 & $2011 / 02 / 24$ & 2 animals, no tracer & 3 & $2.2(0.2)$ & $1.4(0.1)$ \\
2 & $2011 / 02 / 24$ & 2 animals $+{ }^{15} \mathrm{~N}$-tracer & 3 & $0.2(0.1)$ & $0.1(0.0)$ \\
2 & $2011 / 02 / 24$ & 2 empty shell pairs $+{ }^{15} \mathrm{~N}$-tracer & & & \\
& & & 2 & $0.0(0.0)$ & $0.0(0.0)$ \\
3 & $2011 / 03 / 01$ & chamber $+{ }^{15} \mathrm{~N}$-tracer & 2 & $0.0(0.0)$ & $0.0(0.0)$ \\
3 & $2011 / 03 / 01$ & 2 animals, no tracer & 3 & $0.0(0.0)$ & $0.5(0.0)$ \\
3 & $2011 / 03 / 01$ & 2 animals $+{ }^{15} \mathrm{~N}$-tracer & 3 & $0.0(0.0)$ & $0.0(0.0)$ \\
3 & $2011 / 03 / 01$ & 2 fecal pellets $+{ }^{15} \mathrm{~N}$-tracer & & & \\
\hline
\end{tabular}


Figures

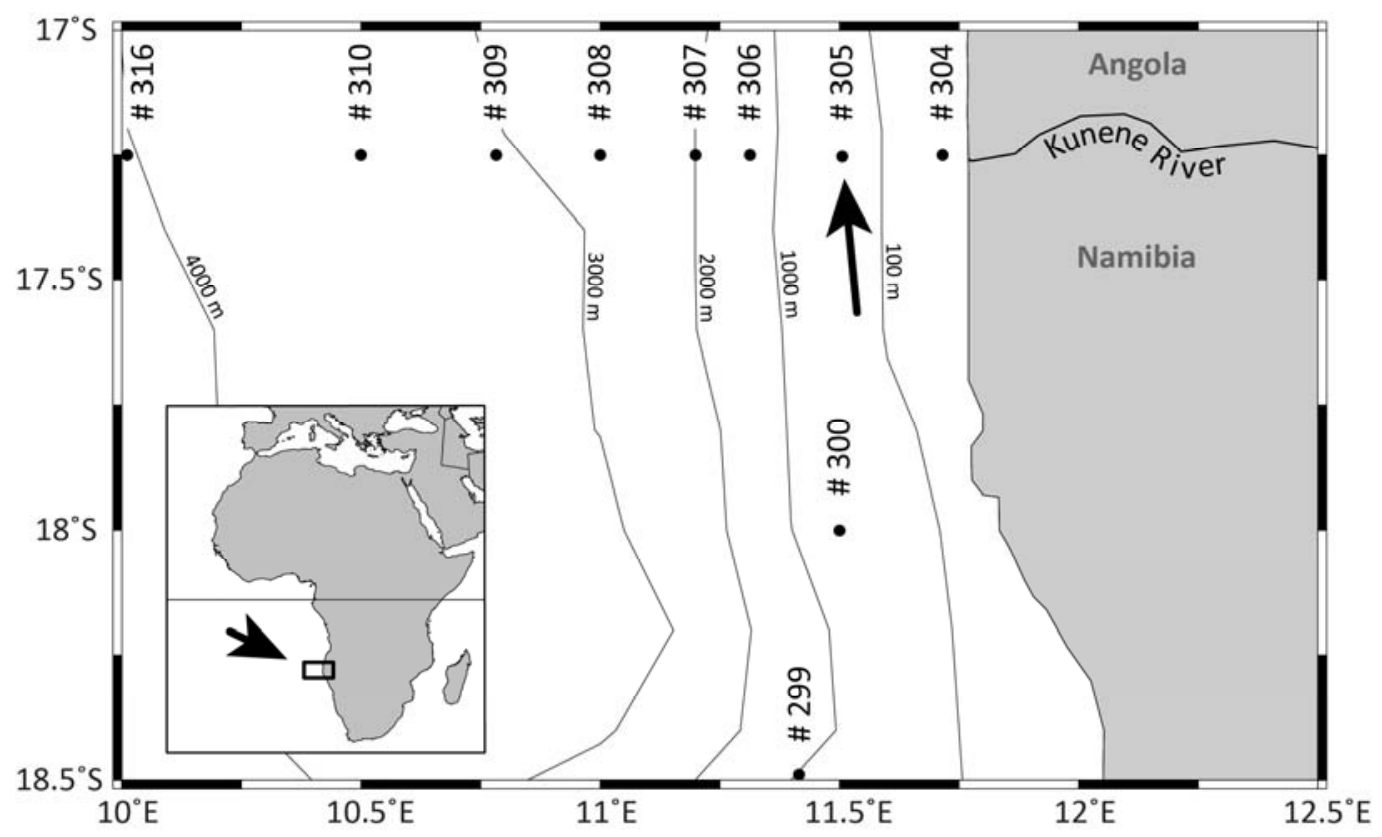

Fig. 1: Map of the study area and position of sampling stations off the mouth of the Kunene River. The arrow indicates the shelf station where the bivalve $N$. bicuspidata was found. The insert shows the working area in the subtropical South Atlantic, southern Africa.

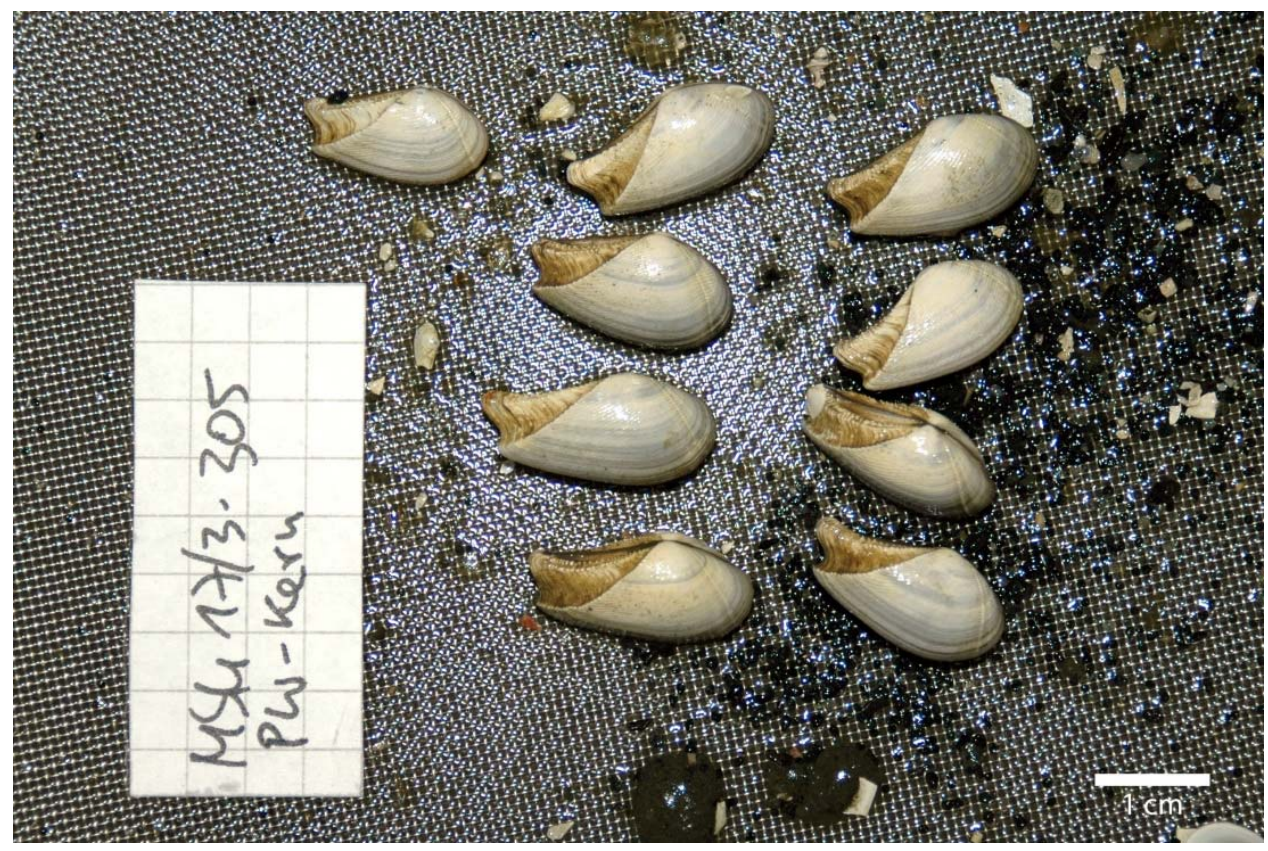

Fig. 2: Living specimens of Nuculana cf. bicuspidata, collected from Multicores from $142 \mathrm{~m}$ water depth (station 305) off Kunene. 


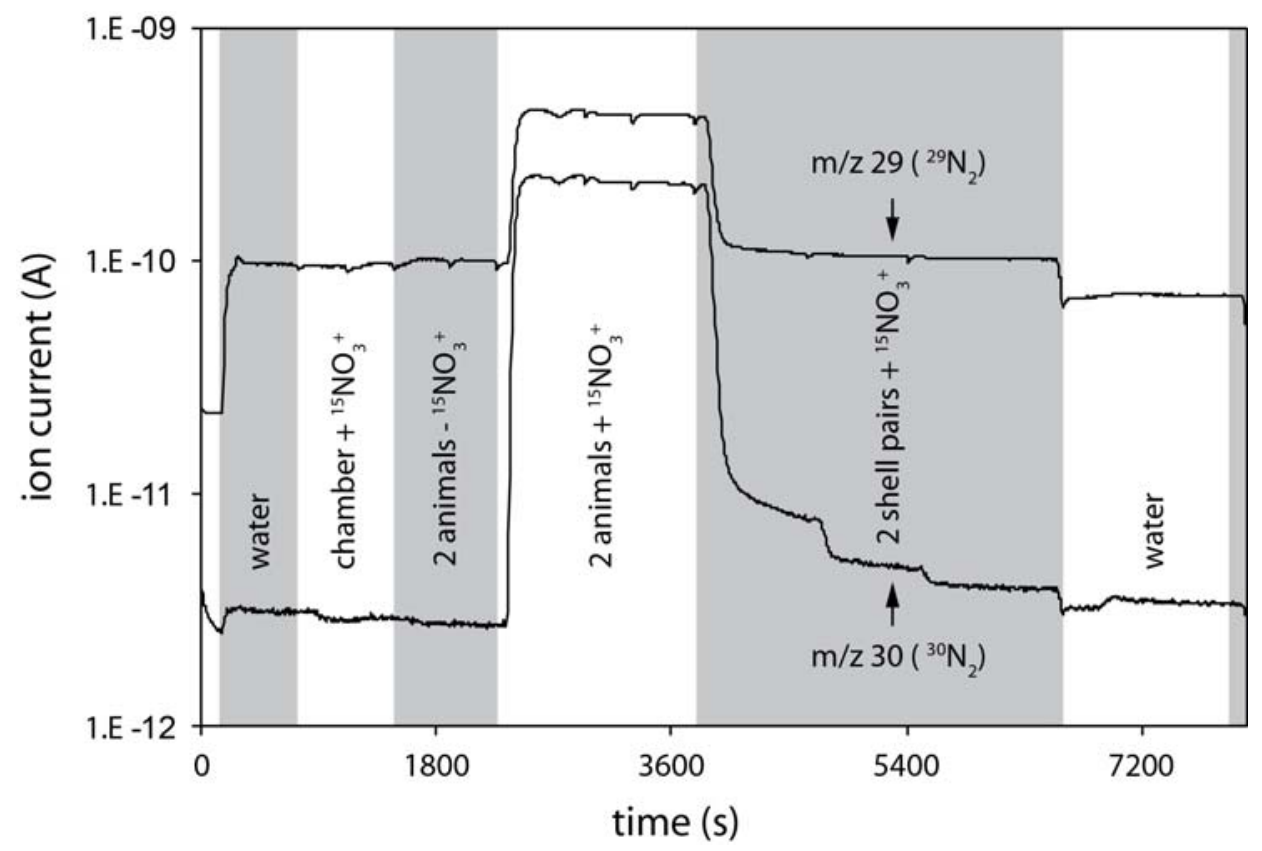

Fig. 3: Signal intensity versus measuring time at $\mathrm{m} / \mathrm{z} 29$ and $\mathrm{m} / \mathrm{z} 30$ during MIMS analysis of anoxic incubation, run 2. Substantial production of labelled ${ }^{29} \mathrm{~N}_{2} /{ }^{30} \mathrm{~N}_{2}$ was observed only in treatments with living animals ( $\mathrm{t}=2250-3600 \mathrm{~s})$ and to a lesser extend in treatments with empty shells $(\mathrm{t}=3650-5730)$. 